\title{
Evaluating the effectiveness of an inactivated vaccine from Anaplasma marginale derived from tick cell culture
}

\author{
Avaliação da eficácia de uma vacina inativada de Anaplasma marginale \\ derivada de cultura de células de carrapato \\ Pedro Veloso Facury Lasmarr ${ }^{1}$; Antônio Último de Carvalho ${ }^{1}$; Elias Jorge Facury Filho ${ }^{1}$; \\ Camila Valgas Bastos²; Múcio Flávio Barbosa Ribeiro ${ }^{2 *}$

\begin{abstract}
${ }^{1}$ Departamento de Clínica da Escola de Veterinaria, Universidade Federal de Minas Gerais - UFMG, Belo Horizonte, MG, Brasil
${ }^{2}$ Departamento de Parasitologia, Instituto de Ciências Biológicas, Universidade Federal de Minas Gerais - UFMG, Belo Horizonte, MG, Brasil

Received July 11, 2011

Accepted February 2, 2012
\end{abstract}

\begin{abstract}
The protective efficacy of an inactivated vaccine from Anaplasma marginale that was cultured in tick cells (IDE8) for use against bovine anaplasmosis was evaluated. Five calves (Group 1) were inoculated subcutaneously, at 21-day intervals, with three doses of vaccine containing $3 \times 10^{9} \mathrm{~A}$. marginale initial bodies. Five control calves received saline solution alone (Group 2). Thirty-two days after the final inoculation, all the calves were challenged with approximately $3 \times 10^{5}$ erythrocytes infected with $A$. marginale high-virulence isolate (UFMG2). The Group 1 calves seroconverted 14 days after the second dose of vaccine. After the challenge, all the animals showed patent rickettsemia. There was no significant difference ( $\mathrm{p}>0.05$ ) between the Group 1 and 2 calves during the incubation period, patency period or convalescence period. All the animals required treatment to prevent death. The results suggest that the inactivated vaccine from $A$. marginale produced in IDE8 induced seroconversion in calves, but was not effective for preventing anaplasmosis induced by the UFMG2 isolate under the conditions of this experiment.
\end{abstract}

Keywords: Anaplasma marginale, vaccination, inactivated vaccine, IDE8.

\section{Resumo}

Foi avaliada a eficácia de uma vacina protetora para Anaplasma marginale cultivada em células de carrapato (IDE8) para uso contra a anaplasmose bovina. Cinco bezerros (Grupo 1) foram inoculados por via subcutânea com três doses, intervalados de 21 dias, de vacina contendo $3 \times 10^{9}$ corpúsculos iniciais de $A$. marginale inicial. Cinco bezerros do grupo controle receberam apenas solução salina (Grupo 2). Trinta e dois dias após a inoculação final, todos os bezerros foram desafiados com aproximadamente $3 \times 10^{5}$ eritrócitos infectados com isolado de $A$. marginale alta virulência (UFMG2). Os bezerros do Grupo 1 soroconverteram-se 14 dias após a segunda dose da vacina. Após o desafio, todos os animais mostraram riquestsemia patente. Não houve diferença significativa ( $p>0,05)$ entre bezerros do Grupo 1 e 2 em período de incubaçáo, período de patência, ou período de convalescença. Todos os animais necessitaram de tratamento para prevenir a morte. Os resultados sugerem que uma vacina inativada de $A$. marginale, produzida em IDE8, induz soroconversão em bezerros, mas não é eficaz na prevenção de anaplasmose induzida pelo isolado UFMG2 nas condições deste experimento.

Palavras-chave: Anaplasma marginale, vacinação, vacina inativada, IDE8.

\section{Introduction}

Bovine anaplasmosis affects the health of livestock produced worldwide. This disease is caused by intra-erythrocytic rickettsia due to Anaplasma marginale, which is transmitted in South America by Rhipicephalus (Boophilus) microplus and hematophagous flies

\footnotetext{
*Corresponding author: Múcio Flávio Barbosa Ribeiro Departamento de Parasitologia, Instituto de Ciências Biológicas,

Universidade Federal de Minas Gerais - UFMG, Av. Antônio Carlos, 6627,

CEP 31270-901, Belo Horizonte, MG, Brasil

e-mail: muciobr@icb.ufmg.br
}

(GUGLIELMONE, 1995). Most areas of Brazil have climatic conditions that are favorable for development of these vectors throughout the year, thus enabling transmission of $A$. marginale to calves that are more resistant to infection. This defines areas of enzootic stability, in the southeastern region (RIBEIRO et al., 1984; SOUZA et al., 2000, 2001) and northeastern region (BARROS et al., 2005), where outbreaks of anaplasmosis in adult cattle have not generally been observed. 
However, in some areas of northeastern Brazil (OLIVEIRA et al., 1992) and in the southern region (ARTILES et al., 1995), the climatic and ecological conditions are not favorable for tick and fly development in all seasons. In these areas, most adult cattle do not encounter $A$. marginale infection when immature and are vulnerable to outbreaks with a high mortality rate. This characterizes an area of enzootic instability (GUGLIELMONE, 1995). Even in a stable area, measures for vector control and for reducing contact between calves and vectors may be adopted, thereby fostering the development of an unstable situation with serious consequences.

In areas that are endemic for anaplasmosis, control measures are not intended to prevent infection but to reduce the occurrences of clinical cases and animal mortality due to acute rickettsemia and subsequently diminished blood packed cell volume (PCV). In areas of enzootic instability, administration of antibiotics or inoculation of calves with live vaccine has been used (RIBEIRO et al., 2003). However, adult cattle with no prior exposure are highly susceptible to developing clinical disease, even when inoculated with a sample of low virulence. Preventing mortality among these animals in an area that is endemic for anaplasmosis is a major challenge.

Inactivated vaccines from $A$. marginale were used in the United States until 1999 (KOCAN et al., 2000). Their withdrawal from the market was related to the difficulty in purifying rickettsia, the need for $A$. marginale-free calves for production of antigen, the frequency of booster applications and difficulty in standardizing the vaccine (KOCAN et al., 2000). With the development of A. marginale cultures in embryonic cells of the tick Ixodes scapularis (IDE8) (MUNDERLOH et al., 1994), several of these issues have been resolved. The observation that immunization with inactivated organisms derived from tick cultures induces protective immunity against challenge with $A$. marginale (DE LA FUENTE, 2002, 2003) shows that this is a promising control measure.

The aim of the present study was to evaluate the protective capability of an inactivated vaccine, produced with A. marginale cultured in embryonic cells of Ixodes scapularis (IDE8), among calves that were experimentally challenged with a highly pathogenic A. marginale isolate.

\section{Material and Methods}

The IDE 8 cells were maintained in vials containing $5 \mathrm{~mL}$ of L-15 medium (Sigma) at pH 7.2, supplemented with 5\% fetal bovine serum (FBS) (Sigma), 10\% tryptose phosphate broth (Sigma), 0.1\% bovine lipoprotein concentrate (LBC) (Sigma), $0.1 \%$ L-glutamine and $0.1 \%$ antibiotic (penicillin/streptomycin) (MUNDERLOH et al., 1994). The temperature was maintained at $30{ }^{\circ} \mathrm{C}\left( \pm 2{ }^{\circ} \mathrm{C}\right)$. The medium was changed every week and culturing was carried out every 14 days.

\section{Preparation of inactivated vaccine from Anaplasma marginale}

Culturing of Brazilian strains of $A$. marginale in IDE8 cells was described previously (BASTOS et al., 2009). Briefly, monolayers of IDE8 cells were inoculated with blood containing UFMG1 and UFMG2 isolates from $A$. marginale that had been cryopreserved in liquid nitrogen. Approximately 14 days after inoculation, colonies of $A$. marginale were observed in cytospin cell smears stained with Giemsa. Subsequent infection was produced by transferring infected cells to uninfected cells. Infected IDE8 were maintained with L-15B medium supplemented with MOPS and held at $34^{\circ} \mathrm{C}$.

When the level of infection reached 70 to $80 \%$ of the cells, they were harvested and centrifuged at $9000 \mathrm{~g}$ for 15 minutes at $4{ }^{\circ} \mathrm{C}$. The pellet that formed was homogenized and incubated with trypsin for 20 minutes at $37^{\circ} \mathrm{C}$. After addition of sterile PBS, the cells were disrupted mechanically and centrifuged at $2300 \mathrm{~g}$ for 5 minutes at $4^{\circ} \mathrm{C}$. $A$. marginale initial bodies in the supernatant were quantified in a hematimetric chamber and the volume was adjusted to $2 \mathrm{~mL}$. Each dose contained approximately $1.5 \times 10^{9} \mathrm{~A}$. marginale initial bodies of each isolate. The antigen was inactivated by adding $\beta$-propiolactone at a concentration of $0.4 \%$ at $4{ }^{\circ} \mathrm{C}$ for 30 minutes. Subsequently, the antigen was emulsified in oil adjuvant (Emulsigen ${ }^{\oplus}$, MVP Laboratories, USA) at a ratio of 20:80 (v:v). The emulsion was prepared by shaking the reagents in a vortex device for approximately 5 minutes, at room temperature.

\section{Experimental animals}

Ten male Friesian calves were kept in a tie stall barn from birth and were sprayed once a week with deltamethrin (Butox, Chemo), in order to keep them free of ticks and biting flies. Blood samples were collected every week for preparation of Giemsa-stained smears to detect $A$. marginale infection. The packed cell volume (PCV) was determined using microhematocrit, and antibodies to A. marginale, Babesia bovis and B. bigemina were detected using the indirect fluorescent antibody test (IFAT) (IICA, 1987). At the start of the experiment, all the calves were approximately 90 days old and had been declared to be free of $A$. marginale infection.

Five calves were randomly assigned to each of two groups. Group 1 was vaccinated with the inactivated vaccine from A. marginale, and Group 2 (controls) was treated with saline. For immunization, the calves were inoculated with three subcutaneous doses of the vaccine at intervals of 21 days. Group 2 was injected with saline emulsified in oil, on the same schedule.

All the calves were challenged with $3 \times 10^{5}$ erythrocytes infected with a blood stabilate that had been infected with an UFMG2 isolate of $A$. marginale, 32 days after the final vaccination.

\section{Monitoring of the experimental groups}

Calf infections were monitored by examining blood smears under a microscope and assessing the PCV every day after the onset of infection. The calves were examined daily for clinical signs, including body temperature and heart and respiratory rates. The calves' rickettsemia levels were measured from blood smears stained with Panoptic (Laborclin, Paraná, Brazil); 40 microscopic fields were counted (IICA, 1987). The PCV was measured using microhematocrit from blood samples collected in EDTA tubes from the jugular vein.

Calves showing clinical signs and a PCV lower than 10\% were treated with enrofloxacin at a dose of $7.5 \mathrm{mg} \mathrm{kg}^{-1}$ of body weight in a single dose. The clinical parameters, rickettsemia levels and 
PCV of each calf were analyzed. The first day when the PCV was found to be less than $10 \%$ was designated day zero, and subsequent data was referenced to this day. The incubation period (IP) was defined as the interval from the day of challenge-exposure to the day of infection onset. The patent period (PP) was measured from the day when $A$. marginale was first detected to the day of enrofloxacin treatment, and the convalescent period (CP) was from the treatment day to the day when the PCV returned to 26\% (MEYER et al., 1995).

This study was approved by the Ethics Committee for Animal Experimentation (CETEA/UFMG, Belo Horizonte, MG, Brazil), under protocol no 41/06.

\section{Humoral immunity}

Blood samples were collected in EDTA tubes, before the first vaccination and 14 days after each vaccination. The blood was centrifuged at $1500 \mathrm{~g}$ for 10 minutes, and the plasma was harvested and frozen at $-20{ }^{\circ} \mathrm{C}$. Total IgG for $A$. marginale was measured by means of IFAT, using serial double dilutions of plasma samples. Samples were considered positive when fluorescence was produced at dilutions $\geq 1: 40$ (IICA, 1987)

\section{Statistical analysis}

In relation to rickettsemia and $\mathrm{PCV}$, the experimental design consisted of a completely randomized split plot (SAMPAIO, 2007), with five repetitions of each treatment (five calves). The plots were composed of the vaccinated and control groups and the subplots were composed of the numbers of days in the disease patency and convalescence periods. The Fisher test was used to compare the mean PCVs. The rickettsemia data did not adhere to the principles of normality and homogeneity, and treatment means were therefore compared using the Kruskal-Wallis test (SAMPAIO, 2007). For IP, PP and CP data, the experimental design was randomized, consisting of two treatments (groups) and five repetitions (calves). The Fisher test was used to compare means between the groups for PP and CP. The incubation period did not show normal distribution and homogeneity of variance and was also analyzed using the Kruskal-Wallis test (SAMPAIO, 2007).

\section{Results}

\section{Seroconversion}

The animals immunized with inactivated vaccines from cell culture-derived $A$. marginale (Group 1) seroconverted with a titration of 320,14 days after the second dose of vaccine. The unvaccinated group remained seronegative until the challenge, thus showing the absence of natural transmission of anaplasmosis during the experiment. On the day of challenge the mean antibody titer was 1280 .

\section{Incubation period, patency period, and convalescence period}

All the animals in both groups showed patent rickettsemia following the challenge with the UFMG2 isolate. There was no significant difference $(p>0.05)$ between Group 1 and 2 during the
IP, PP or CP (Table 1). The average IP was 20 days, the PP ranged from 10.4 to 12.3 days, and the CP ranged from 7.0 to 9.3 days.

\section{Evaluation of rickettsemia}

Calves in Group 1 developed a low levels of rickettsemia, but this was not significantly different from Group 2 ( $p>0.05$ ) (Table 2). The rickettsemia levels were evaluated by means of blood smears during the PP and CP (days - 6 to 12), and showed their maximum values until the day of lowest hematocrit (day 0 ). Thereafter, the rickettsemia level showed a rapid decline from day 1 to day 4 , when it stabilized (Table 2).

\section{Packed cell volume}

When the PCV levels were evaluated using the Fisher test, no significant differences $(\mathrm{p}>0.05)$ were detected between Groups 1 and 2. Prior to day -6 , the animals showed average PCV, within normal limits (between 30 and 35\%) (data not shown). During the PP (from day -6 to day 0), Groups 1 and 2 showed similar decreases in PCV, reaching a minimum value of $10 \%$ on day zero, when they were treated. On the next day, the PCV began to recover, reaching normal limits $(\mathrm{PCV} \geq 26 \%$ ) around day 11 (Table 3 ).

\section{Discussion}

One of the biggest barriers to the production of inactivated vaccine from $A$. marginale using blood from experimentally inoculated animals is the presence of erythrocyte stroma, which results in neonatal isohemolytic anemia in calves after they ingest colostrum from immunized dams (DENNIS et al., 1970). Culturing of $A$. marginale in tick cells has eliminated this factor and opened up new avenues for developing inactivated vaccine.

In this experiment of the present study, animals inoculated with inactivated vaccine from $A$. marginale cultured in IDE8 showed a rapid humoral immune response, thereby confirming the observations of Kocan et al. (2001), de La Fuente et al. (2002) and Garcia-Garcia et al. (2004a). It has been found that in isolates of $A$. marginale grown in IDE8, surface antigens (MSPs) are conserved (BARBET et al., 1999) and that the protective response to infection is linked to the MSP-specific antibody levels (TEBELE et al., 1991). In addition, the adjuvant used in vaccine preparation for the present (Emulsigen ${ }^{\oplus}$ ) has the potential to elicit higher levels of humoral antibodies, more rapid onset of immunity

Table 1. Mean values (days) for incubation period (IP), patency period (PP) and convalescence period (CP), among animals immunized with cell culture-derived Anaplasma marginale after challenge with the UFMG2 Anaplasma marginale isolate.

\begin{tabular}{cccc}
\hline Group & IP $^{\mathbf{1}}$ & $\mathbf{P P}^{\mathbf{2}}$ & $\mathbf{C P}^{\mathbf{2}}$ \\
\hline Vaccinated & $20.0^{\mathrm{A}}$ & $10.4^{\mathrm{A}}$ & $7.0^{\mathrm{A}}$ \\
Control & $20.0^{\mathrm{A}}$ & $12.3^{\mathrm{A}}$ & $9.3^{\mathrm{A}}$ \\
\hline
\end{tabular}

${ }^{1}$ Means with same superscript are similar according to the Kruskal-Wallis test $(p>0.05) .{ }^{2}$ Means with same superscript are similar according to the Fisher test $(\mathrm{p}>0.05)$. 
Table 2. Mean rickettsemia values (\%) among animals immunized with cell culture-derived Anaplasma marginale and challenged with the UFMG2 Anaplasma marginale isolate.

\begin{tabular}{|c|c|c|c|c|c|c|c|c|c|c|c|c|c|c|c|c|c|c|c|c|}
\hline \multirow[b]{2}{*}{ Group } & \multicolumn{20}{|c|}{ Days } \\
\hline & -6 & -5 & -4 & -3 & -2 & -1 & $\mathbf{0}$ & 1 & 2 & 3 & 4 & 5 & 6 & 7 & 8 & 9 & 10 & 11 & 12 & Mean \\
\hline Vaccinated & 0.8 & 1.4 & 5.8 & 8.7 & 10.2 & 7.4 & 8.9 & 4.0 & 0.3 & 0.7 & 0.0 & 0.0 & 0,0 & 0.0 & 0.0 & 0.0 & 0.0 & 0.0 & 0.0 & $2.5^{\mathrm{A}}$ \\
\hline Control & 0.1 & 2.7 & 3.5 & 9.2 & 8.2 & 10.3 & 10.4 & 4.6 & 0.9 & 0.5 & 0.1 & 1.9 & 0.0 & 0.0 & 0.0 & 0.0 & 0.0 & 0.0 & 0.0 & $2.8^{\mathrm{A}}$ \\
\hline
\end{tabular}

Day 0: day of lowest PCV.

Table 3. Packed cell volume of animals immunized with cell culture-derived Anaplasma marginale and challenged with the UFMG2 Anaplasma marginale isolate.

\begin{tabular}{|c|c|c|c|c|c|c|c|c|c|c|c|c|c|c|c|c|c|c|c|}
\hline \multirow[b]{2}{*}{ Groups } & \multicolumn{19}{|c|}{ Days } \\
\hline & -6 & -5 & -4 & -3 & -2 & -1 & 0 & 1 & 2 & 3 & 4 & 5 & 6 & 7 & 8 & 9 & 10 & 11 & Mean \\
\hline Vaccinated & 27.3 & 26.5 & 24.8 & 19.3 & 15.7 & 13.3 & 10.5 & 12.8 & 14.0 & 16.0 & 17.0 & 18.8 & 20.4 & 21.6 & 21.6 & 22.2 & 23.5 & 26.3 & $19.5^{\mathrm{A}}$ \\
\hline Control & 27.4 & 25.6 & 22.0 & 20.4 & 19.2 & 16.2 & 13.6 & 16.2 & 16.8 & 18.4 & 20.6 & 22.4 & 21.5 & 22.8 & 25.0 & 24.3 & 26.3 & 26.8 & $21.4^{\mathrm{A}}$ \\
\hline
\end{tabular}

Day 0: day of lowest PCV.

and enhanced protection, compared with conventional adjuvants (HISZCZYNSKA-SAWICKA et al., 2010).

Although seroconversion took place among the vaccinated calves, the antibodies were not able to prevent clinical anaplasmosis or to reduce its effects. The vaccinated animals showed a clinical picture similar to that of the control group, and the IP, PP and CP were also similar. Presence of antibodies does not signify effective protection against anaplasmosis in animals, since administration of immune serum from donors with high titers of antibodies has not been shown to protect animals against challenge with $A$. marginale (GALE et al., 1992). Immunity against anaplasmosis involves not only humoral immunity but also a $\mathrm{T}_{\mathrm{h}}$ Type 1 cell immune response, together with production of interferon gamma (IFNg), interleukin (IL) 2 and IL12, which are able to reduce the clinical effects of the disease (BROWN et al., 1998; DE LA FUENTE et al., 2002).

Through inoculation with $A$. marginale initial bodies, all surface antigens are exposed to the host's immune system. Five major surface proteins of $A$. marginale have been characterized: MSP1, MSP2, MSP3, MSP4 and MSP5. MSP1 has been implicated in induction of protective immunity in mice immunized with A. marginale (PALMER et al., 1986). MSP1 is composed of two structurally unrelated proteins, MSP1a and MSP1b, which have been shown to be involved in adhesion of rickettsiae to host cells. However, proteins MSP1a and MSP1b produced during multiplication of rickettsia in tick cells may vary from those in the erythrocytes of cattle. The amount of MSP1a in samples of A. marginale in erythrocytes is higher than when grown in tick cells (GARCIA-GARCIA et al., 2004a; KOCAN et al., 2004), unlike MSP1b, which shows no change in production whether derived from erythrocytes or tick cells. Animals immunized with antigens of $A$. marginale cultured in IDE8 cells show a predominantly humoral response against MSP1b, while mice immunized with antigens from infected erythrocytes develop a response against MSP1a (KOCAN et al. 2001; DE LA FUENTE et al., 2002). This suggests that regulation of the expression of MSP1a in erythrocytes may result in production of molecules that do not form complexes with MSP1a and MSP1b, thereby increasing the chance of transmission to ticks when they feed on infected bovine erythrocytes (GARCIA-GARCIA et al., 2004b).
In addition to involvement in adhesion, infection and transmission of $A$. marginale to ticks, MSP1a also contributes towards immune protection of cattle (PALMER et al., 1986; McGAREY et al., 1994; DE LA FUENTE et al., 2003). Brown et al. (2001) found that the response to CD4+ T cells preferentially recognized the carboxyl terminal of MSP1a in cattle immunized with purified MSP1 complex, which provided protection after challenge with the homologous isolate of $A$. marginale. The animal protection in the present study may have been insufficient, because the $A$. marginale used was derived from IDE- 8 tick cell cultures, and therefore the MSP1a production was insufficient for an effective $T_{h} 1$ response.

Genome sequencing and proteomic analysis on $A$. marginale membrane proteins have identified a variety of other surface antigens (AGNES et al., 2011, DARK et al., 2011), including in Brazilian isolates (VIDOTTO et al., 2008; GUEDES JUNIOR et al., 2010). Nonetheless, although all these studies were conducted using $A$. marginale from infected cattle blood, no information on the influence of in vitro cultivation in tick cells on these proteins has been produced.

Another factor that may be associated with the failure of the inactivated vaccine to prevent clinical disease is the isolate used in the challenge. The UFMG2 isolate has been demonstrated to present high virulence, causing clinical disease in young and adult animals with an incubation period of 21 days (BASTOS et al., 2010). However, challenge with a single dose of a high concentration of erythrocytes from a virulent isolate does not mimic natural infections in which animals are continuously exposed to low concentrations for long periods of time (PACHECO et al., 2004). Success in using inactivated $A$. marginale vaccine grown in tick cells, with low-virulence isolates as the challenge, has been reported. The control animals showed a reduction in PCV, but not to less than 20\% (KOCAN et al., 2001; DE LA FUENTE et al., 2002). In the present experiment, all the animals inoculated with the UFMG2 isolate developed severe anemia and, when the PCV reached $10 \%$, were treated to ensure survival.

We conclude that inactivated vaccines derived from culturing A. marginale in embryonic cells of Ixodes scapularis induced seroconversion in calves, but were not effective for preventing the anaplasmosis induced by challenge using the UFMG2 isolate 
under the conditions of this experiment. Studies using $A$. marginale isolates of lower virulent for challenge in vaccinated animals, or using changes to the composition of the inactivated vaccine should be conducted.

\section{Acknowledgements}

We thank the Brazilian National Council for Scientific and Technological Development (CNPq) and the Research Support Foundation of the State of Minas Gerais (FAPEMIG) for their financial support.

\section{References}

Agnes JT, Brayton KA, LaFollett M, Norimine J, Brown WC, Palmer GH. Identification of Anaplasma marginale outer membrane protein antigens conserved between $A$. marginale sensu stricto strains and the live A. marginale subsp.centrale vaccine. Infect Immun 2011; 79: 1311-1318. PMid:21189322 PMCid:3067503. http://dx.doi.org/10.1128/ IAI.01174-10

Artiles J, Alves-Branco FPJ, Martins JR. Prevalência de Babesia bovis, Babesia bigemina e Anaplasma marginale no município de Bagé, RS. Rev Bras Parasitol Vet 1995; 4(supl.1): 179.

Barbet AF, Blentlinger R, Lundgren AM, Blouin EF, Kocan KM. Comparison of surface proteins of Anaplasma marginale grown in tick cell culture, tick salivary glands and cattle. Infect Immun 1999; 67(1): 102-107. PMid:9864202 PMCid:96283.

Barros SL, Madruga CR, Araújo FR, Menk CF, De Almeida MAO, Melo EP, et al. Serological survey of Babesia bovis, Babesia bigemina, and Anaplasma marginale antibodies in cattle from the semi-arid region of the state of Bahia, Brazil, by enzyme-linked immunosorbent assays. Mem Inst Oswaldo Cruz 2005; 100(6): 513-517. http://dx.doi.org/10.1590/ S0074-02762005000600003

Bastos CV, Passos LMF, Vasconcelos MM, Ribeiro MFB. In vitro establishment and propagation of a Brazilian strain of Anaplasma marginale with appendage in IDE8 (Ixodes scapularis) cells. Braz J Microbiol 2009; 40: 395-403. http://dx.doi.org/10.1590/ S1517-83822009000200034

Bastos CV, Passos LMF, Facury-Filho EJ; Rabelo EM, De La Fuente $\mathrm{J}$, Ribeiro MFB. Protection in the absence of exclusion between two Brazilian isolates of Anaplasma marginale in experimentally infected calves. Vet J 2010; 186(3): 374-378. PMid:19837622. http://dx.doi. org/10.1016/j.tvjl.2009.09.013

Brown WC, Shkap V, Zhu D, McGuire TC, Tuo W, McElwain TF, Palmer GH. CD4+ T-lymphocyte and immunoglobulin G2 responses in calves immunized with Anaplasma marginale outer membranes and protected against homologous challenge. Infect Immun 1998; 66(11): 5406-5413. PMid:9784551 PMCid:108677.

Brown WC, Palmer GH, Lewin HA, McGuire TC. CD4+ T lymphocytes from calves immunized with Anaplasma marginale major surface protein 1 (MSP1), a heteromeric complex of MSP1a and MSP1b, preferentially recognize the MSP1a carboxyl terminus that is conserved among strains. Infect Immun 2001; 69(11): 6853-6862. PMid:11598059 PMCid:100064. http://dx.doi.org/10.1128/IAI.69.11.6853-6862.2001

Dark MJ, Al-Khedery B, Barbet AF. Multistrain genome analysis identifies candidate vaccine antigens of Anaplasma marginale.
Vaccine 2011; 29(31): 4923-4932. PMid:21596083 PMCid:3133685. http://dx.doi.org/10.1016/j.vaccine.2011.04.131

Dennis RA, O'Hara PJ, Young MF, Dorris KD. Neonatal immunohemolytic anemia and icterus of calves. J Am Vet Med Assoc 1970; 156(12): 1861-1869. PMid:5464261.

de La Fuente J, Kocan KM, Garcia-Garcia JC, Blouin EF, Claypool PL, Saliki JT. Vaccination of cattle with Anaplasma marginale derived from tick cell culture and bovine erythrocytes followed by challenge-exposure with infected ticks. Vet Microbiol 2002; 89: 239-251. http://dx.doi. org/10.1016/S0378-1135(02)00206-7

de La Fuente, J, Kocan KM, Garcia-Garcia JC, Blouin EF, Halbu T, Onet $\mathrm{V}$. Antibodies to Anaplasma marginale major surface protein 1a reduce infectivity for ticks. J Appl Res Vet Med 2003; 1: 285-292.

Gale KR, Leatch G, Gartside M, Dimmock CM. Anaplasma marginale: failure of sera from immune cattle to confer protection in passive- transfer experiments. Parasitol Res 1992; 78(5): 410-415. PMid:1495919. http:// dx.doi.org/10.1007/BF00931697

Garcia-Garcia JC, De La Fuente J, Kocan KM, Blouin EF, Halbur $\mathrm{T}$, Onet VC, et al. Mapping of B-cell epitopes in the N-terminal repeated peptides of Anaplasma marginale major surface protein 1a and characterization of the humoral immune response of cattle immunized with recombinant and whole organism antigens. Vet Immunol Immunopathol 2004a; 98(3-4): 137-151. PMid:15010223. http://dx.doi. org/10.1016/j.vetimm.2003.11.003

Garcia-Garcia JC, De La Fuente J, Blouin EF, Johnson TJ, Halbur $\mathrm{T}$, Onet VC, et al. Differential expression of the mspl $\alpha$ gene of Anaplasma marginale occurs in bovine erythrocytes and tick cells. Vet Microbiol 2004b; 98(3-4): 261-272. PMid:15036535. http://dx.doi. org/10.1016/j.vetmic.2003.10.021

Guglielmone AA. Epidemiology of babesiosis and anaplasmosis in South and Central America. Vet Parasitol 1995; 57(1-3): 109-119. http://dx.doi. org/10.1016/0304-4017(94)03115-D

Hiszczynska-Sawicka E, Li H, Xu JB, Oledzka G, Kur J, Bickerstaffe $\mathrm{R}$, et al. Comparison of immune response in sheep immunized with DNA vaccine encoding Toxoplasma gondii GRA7 antigen in different adjuvant formulations. Exp Parasitol 2010; 124(4): 365-372. PMid:19962376. http://dx.doi.org/10.1016/j.exppara.2009.11.015

Instituto Interamericano de Cooperação para a Agricultura - IICA. Técnicas para el Diagnostico de Babesiosis y anaplasmosis Bovine. San José, Costa Rica: IICA;1987.

Guedes Junior DS, Araújo FR, Almeida Junior NF, Adi SS, Cheung LM, Fragoso SP, et al. Analysis of membrane protein genes in a Brazilian isolate of Anaplasma marginale. Mem Inst Oswaldo Cruz 2010; 105(7): 843-849. http://dx.doi.org/10.1590/S0074-02762010000700001

Kocan K M, Halbur T, Blouin E F, Onet V, De La Fuente J,Garcia-Garcia JC, et al. Imunization of cattle with Anaplasma marginale derived from tick cell culture. Vet Parasitol 2001; 102(1-2): 151-161. http://dx.doi. org/10.1016/S0304-4017(01)00519-2

Kocan KM, Blouin EF, Barbet AF. Anaplasmosis control. Past, present and future. Ann NY Acad Sci 2000; 916: 501-509. http://dx.doi. org/10.1111/j.1749-6632.2000.tb05329.x

Kocan KM, De La Fuente J, Blouin EF, Garcia-Garcia JC. Anaplasma marginale (Rickettsiales: Anaplasmataceae): recent advances in defining host-pathogen adaptations of a tick-borne rickettsia. Parasitology 2004; 129: S285-S300. PMid:15938516. http://dx.doi. org/10.1017/S0031182003004700 
Meyer DJ, Coles EH, Rich LJ. Medicina de laboratório veterinária Interpretação e diagnóstico. SãoPaulo: Roca LTDA; 1995.

McGarey DJ, Barbet AF, Palmer GH, McGuire TC, Allred DR. Putative adhesins of Anaplasma marginale: major surface polypeptides $1 \mathrm{a}$ and $1 \mathrm{~b}$. Infect Immun 1994; 62(10): 4594-4601. PMid:7927726 PMCid:303148.

Munderloh UG, Liu Y, Wang M, Chen C, Kurtti TJ. Establishment, maintenance and description of cell lines from the tick Ixodes scapularis. J Parasitol 1994; 80(4): 533-543. PMid:8064520. http://dx.doi. org/10.2307/3283188

Oliveira A A, Pedreira P A S, Almeida MRS. Doença de bezerros II. Epidemiologia da anaplasmose no estado do Sergipe. Arq Bras Med Vet Zootec 1992; 44(5): 377-386.

Pacheco RC, Vidotto O, Tamekuni K, Igarashi M, Kawasaki P, Prudêncio LB, et al. Dinâmica da infecção natural pelo Anaplasma marginale em vacas e bezerros da raça Holandesa, na região de Londrina, Estado do Paraná, Brasil. Semin, Cienc Agrar 2004; 25(3): 235-244.

Palmer GH, Barbet AF, Davis WC, Mcguire TC. Immunization with an isolate-common surface protein protects cattle against anaplasmosis. Science 1986; 231(4743): 1299-1302. PMid:3945825. http://dx.doi. org/10.1126/science.3945825

Ribeiro MFB, Patarroyo JHS, Santos JL, Faria JE. Epidemiologia da anaplasmose bovina no estado de Minas Gerais. I. Prevalencia de anticorpos aglutinantes e fluorescentes na zona da mata. Arq Bras Med Vet Zootec 1984; 36: 425-432.
Ribeiro MFB, Facury-Filho EJ, Passos LMF, Saturnino HM, Malacco MAF. Uso de inoculo padronizado de Anaplasma marginale e da quimioprofilaxia no controle da anaplasmose bovina. Arq Bras Med Vet Zootec 2003; 55(1): 21-26. http://dx.doi.org/10.1590/ S0102-09352003000100004

Sampaio IBM. Estatística Aplicada à Experimentação Animal. 3rd ed. Belo Horizonte: FEPMVZ; 2007.

Souza JCP, Soares CO, Massard CL, Scofield A, Fonseca AH. Soroprevalência de Anaplasma marginale em bovinos na mesorregiáo Norte Fluminense. Pesq Vet Bras 2000; 20(3): 97-101. http://dx.doi. org/10.1590/S0100-736X2000000300002

Souza JCP, Soares CO, Madruga CR, Massard CL. Prevalence of antibodies against Anaplasma Marginale (Rickettsiales: Anaplasmataceae) in cattle in the "Médio Paraíba" mesoregion, Brazil. Ciênc Rural 2001; 31(2): 309-314. http://dx.doi.org/10.1590/S0103-84782001000200019

Tebele N, McGuir TC, Palmer GH. Induction of protective immunity by using Anaplasma marginale initial body membranes. Infect Immun 1991; 59(9): 3199-3204. PMid:1715323 PMCid:258153.

Vidotto MC, Venâncio EJ, Vidotto O. Cloning, sequencing and antigenic characterization of rVirB9 of Anaplasma marginale isolated from Paraná State, Brazil. Genet Mol Res 2008; 7(2): 460-466. PMid:18561379. http:// dx.doi.org/10.4238/vol7-2gmr416 